\title{
EFFECT OF SODIUM NITRITE EXPOSURE ON THE IMMUNE RESPONSES AGAINST OF RIFT VALLEY FEVER VACCINE IN MICE
}

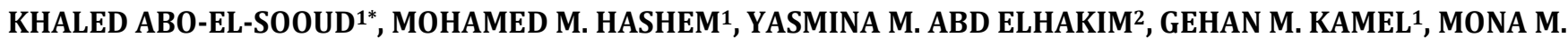 \\ E. ELEIWA ${ }^{3}$, ALI Q. GAB-ALLAHA ${ }^{4}$
}

1Department of Pharmacology, Faculty of Veterinary Medicine, Cairo University, Giza 12211, Egypt, ${ }^{2}$ Department of Forensic Medicine and Toxicology, Faculty of Veterinary Medicine, Zagazig University, Zagazig, Egypt, ${ }^{3}$ Department of Botany, Faculty of Science, Cairo University, Giza, Egypt, ${ }^{4}$ The Holding Company for Biological Products and Vaccines VACSERA

Email: kasooud@cu.edu.eg

Received: 04 Apr 2018 Revised and Accepted: 17 May 2019

ABSTRACT

Objective: Daily exposure to food preservatives constitutes a major crisis to children especially during vaccination so; the aim of the study is to assess the effect of sodium nitrite on the immune responses against Rift Valley fever vaccine (RVFV) in Swiss mice.

Methods: Mice were divided into four equal groups: group 1 (control) was orally administrated with distilled water ( $2 \mathrm{ml} / \mathrm{kg}$ b. wt.); group 2 was orally administrated with the acceptable daily intake (ADI) of sodium nitrite $0.07 \mathrm{mg} / \mathrm{kg} \mathrm{b}$. wt. daily for $21 \mathrm{~d}$, group 3 was vaccinated with inactivated RVFV two times and group 4 was orally given sodium nitrite and vaccinated as group 3. Blood samples were collected from all groups two weeks after booster vaccination. The leucocytic indices and the neutrophil-lymphocyte ratio (NLR) were determined to assess the cell-mediated immunity. The humoral immunity was evaluated using direct enzyme-linked immune-sorbent assay (ELISA) test and serum neutralization test (SNT).

Results: Sodium nitrite significantly increased the neutrophil index and the NLR whereas; it decreased the total leucocytic count and lymphocyte index in both non-vaccinated and vaccinated mice. Moreover, sodium nitrite significantly decreased both the IgG titer and the efficiency of vaccination through increasing the $\mathrm{ED}_{50}$ value.

Conclusion: Sodium nitrite existed an immune-suppressive effect on both cellular and humoral immune responses in mice.

Keywords: Sodium nitrite, Rift Valley fever, Immunity, Antibodies, Challenge

(C) 2019 The Authors. Published by Innovare Academic Sciences Pvt Ltd. This is an open access article under the CC BY license (http://creativecommons.org/licenses/by/4.0/) DOI: http://dx.doi.org/10.22159/ijpps.2019v11i7.33443

\section{INTRODUCTION}

Rift Valley fever (RVF) is an insect-borne zoonotic disease throughout tropical African countries [1], and characterized by severe epizootics of abortion in ruminants and meningitis, and/or impairment of vision in man [2], with no specific treatment (Kortekaas, 2014). Due to official and economic challenges, the production of human RVFV has been reluctant nevertheless; high efficacy and safety veterinary vaccines are exclusively developed for livestock [4]. Several mouse and rat models of RVF viral infection have been well distinguished and give a productive technique for vaccine evaluation [5]. Most of the food additives such as preservatives and flavors produced a significant decline in immune responses and an inhibitory effect on the production of oxygen free radicals responsible for the phagocytic effect of neutrophils [6].

The alterations in humoral and cell mediated-immunity were evaluated by estimation of the IgG levels, lymphocyte viability, neutrophil phagocytic activity, total leucocytic count (TLC) and differential leucocytic count (DLC) [7].

Nitrite is an essential curing ingredient responsible for color fixative and preservative in cooked meats, sausages and fish [8] through providing control of the oxidation of lipids, and an effective antimicrobial [9]. Sodium nitrite produced a desirable pink to red color, that is extremely obvious characteristic for consumer acceptance [10]. However, nitrate salts can react with certain amines in food to produce nitrosamines, that are known carcinogens in the food matrix without the addition of external nitrite [11]. The existence of nitrites in food is correlated with an increased risk of gastrointestinal tumors and methemoglobinemia in infants [12]. The incidence of epithelial hyperplasia in the glandular stomach was increased in mice after consuming a high level of sodium nitrite in drinking water [13]. The estimated daily intake (EDI) of nitrite was not the same in all countries, in Korea it is $0.87 \mu \mathrm{g} / \mathrm{kg} /$ day, representing $1.25 \%$ of acceptable daily intake (ADI) assigned by JEFCA [14]. Because of the use of more than one type of such food, the percentage of nitrite content of the daily food consumption may be higher than the admissible level and was nominated by the FDA for toxicity and carcinogenesis studies based on its widespread use in foods [15]. The highest mean dietary exposure of food preservatives was observed in children of 2-7 y age group and the percentage exposure was between 17 to $33 \%$ of the ADI [16]. Thus, the overall exposure should be taken into account in the assessment of the associated risks of sodium nitrite. Consequently, the present study was conducted to determine the effect of ADI doses of sodium nitrite on both cellular and humoral immune responses against RVFV in a murine module to assess the possible hazard effect of sodium nitrite on routine vaccinations.

\section{MATERIALS AND METHODS}

\section{Animals}

Swiss mice weighing 20-25 grams provided by the breeding unit of Holding company for biological products and vaccines (VACSERA) GizaEgypt. Animals were provided with standard pellet food and had free access to drinking water. The study was approved by the institutional animal care and use committee, of Veterinary Medicine, Cairo University (Vet. CU/II/F 2018). The regulations and the ethical guidelines for laboratory animals in accordance with the guidelines contained in the Guide for the Care and Use of Laboratory Animals $8^{\text {th }}$ Edition [17].

\section{Chemicals}

Sodium nitrite: (E250) was purchased as an authentic powder from Sigma-Aldrich Fine Chemicals, St. Louis, MI, USA.

\section{RVFV}

It was obtained from vaccine production department of the holding company for biological products and vaccine (VACSERA) Ministry of 
health. Batch No. 160 used in this work was safe and potent according to the OIE and WHO requirements.

\section{Selection of dose}

The acceptable daily intake (ADI) of sodium nitrite was determined according to the Joint FAO/WHO Expert Committee on Food Additives (JECFA) as $0.07 \mathrm{mg} / \mathrm{kg}$ b. wt. daily based on a nationwide food consumption survey and nitrite/nitrate content in various foodstuffs [15].

\section{Animal grouping and dosing}

Animals were divided into four groups with twenty-five mice in each as follow:

Group I, Distilled water (2 ml/kg b. wt.)

Group II Sodium nitrite $(0.07 \mathrm{mg} / \mathrm{kg} \mathrm{b}$. wt.) orally for $21 \mathrm{~d}$

Group III Distilled water $(2 \mathrm{ml} / \mathrm{kg})$ and vaccinated with inactivated RVFV at a dose of $0.2 \mathrm{ml}$ intra-peritoneal (I/P) injection on the day 21 of the experiment and a booster dose after one week [18].

Group IV Sodium nitrite $(0.07 \mathrm{mg} / \mathrm{kg}$ b. wt.) for $21 \mathrm{~d}$ and vaccinated with inactivated RVFV at a dose of $0.2 \mathrm{ml} \mathrm{I} / \mathrm{P}$ at the day 21 of the experiment and a booster dose after one week.

\section{Blood sampling}

All the animals were sacrificed using cervical dislocation euthanasia after two weeks from the booster dose of vaccination and blood samples were collected for hematological and serological tests.

Two blood samples were collected on EDTA for estimation of total leucocytic (TLC) count and differential leucocytic count (DLC). The further blood sample was collected in a sterile centrifugation tube without anticoagulant for separation of serum for serological tests. The serum samples were inactivated at $56^{\circ} \mathrm{C}$ for $30 \mathrm{~min}$ to destroy most of its viral inhibitory activity.

Serum samples obtained were used for measurement of IgG, antibodies using direct enzyme-linked immune-sorbent assay (ELISA) test, serum neutralization test (SNT) test, and challenge test.

\section{Neutrophil and lymphocyte indices}

Blood samples were incubated for $10 \mathrm{~min}$ at $37^{\circ} \mathrm{C}$ with $80 \mathrm{mg} / \mathrm{ml}$ of nylon fibers and were prepared for DLC after the TLC counts. The product of the TLC and the neutrophil and lymphocyte percentages known as the neutrophil and lymphocyte indices were determined for each of the respective groups [19].

\section{NLR}

The ratio is an adequate immunological parameter of exposure to infection or vaccination in mice. It is reliably easy, rapid and potent to avoid the different extrinsic factors [20].

\section{IgG antibodies}

The accurate quantization of the IgG (Y-chain) antibodies in the serum may be achieved using the direct ELISA test [21]. The virusspecific IgG exists in the serum will bind to the viral antigens using horse reddish peroxidize (HRP) that reacts with ABTS substrate to produce specific color that was estimated using spectrophotometer adjusted at the wavelength of $405 \mathrm{~nm}$.

\section{Serum neutralization test (SNT)}

The assay is a highly specific serological tool to identify the presence and amount of systemic antibodies that combat virus infectivity. The assay is a highly sensitive and specific test to evaluate the titer of neutralizing antibodies especially after vaccination [22].

\section{Challenge test}

Two groups of weaning mice control and sodium nitrite-treated $(21$ d) were inoculated with five-fold serial dilutions with inactivated RVFV (undiluted, 1/5-1/25-1/125-1/625). The groups were challenged after two weeks from booster doses using RVF challenge virus at $1000 \mathrm{LD}_{50} / \mathrm{ml}$ at a dose of $0.2 \mathrm{ml} \mathrm{I} / \mathrm{P}$. The numbers of dead and alive mice were calculated according to the method of Reed and Muench [23], and results were expressed using the reciprocals of the dilutions.

\section{Statistical analysis}

All the values were expressed as mean \pm Standard error (SEM). The data were subjected to student $t$-test using the statistical analysis software (SPSS) Ver. 15, under Windows XP. Comparisons between groups were used to determine the statistical significance between various groups. Differences were considered to be statistically significant when ${ }^{*} \mathrm{p}<0.05$ and ${ }^{* *} \mathrm{p}<0.01$.

\section{RESULTS}

\section{Neutrophil and lymphocyte indices and the NLR}

Sodium nitrite-induced significantly increased the neutrophil index and the NLR whereas; it decreased the total leucocytic count and lymphocyte index in both non-vaccinated and vaccinated mice when compared to group I and group III (table 1). Accordingly, sodium nitrite reduced the cellular immune response.

Table 1: Effect of sodium nitrite on cellular immunity in normal and RVFV-vaccinated mice

\begin{tabular}{lllllll}
\hline Group & W. B. Cs $\left(\mathbf{X 1 0}^{3} / \mathbf{m m}^{3}\right)$ & \% neutrophil & neutrophil index & lymphocyte \% & lymphocyte index & neutrophil-lymphocyte ratio \\
\hline 1 & $4.1 \pm 0.14$ & $28.2 \pm 0.61$ & $115.8 \pm 4.40$ & $63.9 \pm 1.91$ & $262.4 \pm 10.74$ & $0.44 \pm 0.01$ \\
2 & $3.3 \pm 0.11^{* *}$ & $41.2 \pm 1.20^{* *}$ & $135.4 \pm 2.56^{*}$ & $56.6 \pm 1.46^{*}$ & $186.1 \pm 7.89^{* *}$ & $0.73 \pm 0.02^{* *}$ \\
3 & $5.0 \pm 0.18^{*}$ & $20.8 \pm 0.93^{*}$ & $103.9 \pm 6.03^{* *}$ & $78.1 \pm 2.10^{* *}$ & $390.6 \pm 13.64^{* *}$ & $0.27 \pm 0.01^{* *}$ \\
4 & $3.8 \pm 0.10^{*}$ & $36.9 \pm 1.44^{* *}$ & $140.1 \pm 4.15^{*}$ & $62.1 \pm 1.92^{*}$ & $236.0 \pm 6.48^{* *}$ & $0.59 \pm 0.02^{* *}$ \\
\hline
\end{tabular}

mean \pm SEM of mice in each group significance at ${ }^{* *} \mathrm{p}<0.05,{ }^{* *} \mathrm{p}<0.01$ when compared to Group I; $\mathrm{p}<0.05, \cdot \mathrm{p}<0.01$ when compared to Group III. $(\mathrm{n}=25)$.

\section{Estimation of IgG antibodies using ELIZA and SNT}

The tested sera were positive up to dilution $1 / 200$ equal to (log 2.3 All tested sera positive up to dilution $1 / 200$ equal to (log 2.3), the average positive was (472), the average negative (109), the average positive/negative $(\mathrm{P} / \mathrm{N})$ ratio was (4.3) and the cut off value was (218). Sodium nitrite gave positive ELISA titer up to the dilution of $1 / 40$ equal to $(\log 1.6)$ with more than $25 \%$ as compared with the vaccinated group (fig. 1). Additionally; the sodium nitrite results showed that the amount of antibodies in serum samples that protects $50 \%$ of the cells was positive at $1 / 16$ equal to (Log 1.2) and dilution of $1 / 8$ equal to (Log 0.9), respectively. Collectively, sodium nitrite-induced a significant decrease in IgG titer (humoral immune response).

\section{Challenge test}

The $\mathrm{ED}_{50}$ is still a useful and dependable method to indicate that vaccinated animals have responded to vaccination. The results of the challenge test showed that $50 \%$ of deaths in vaccinated-mice were in between dilution $1 / 125$ to $1 / 625$ and $\mathrm{ED}_{50}$ was $=0.01$ (table 2).

The standard WHO and OLE requirements of $\mathrm{ED}_{50}$ is 0.02 , the more $\mathrm{ED}_{50}$ the more potent the vaccine. While in vaccinated sodium nitrite-administered mice, the $\mathrm{ED}_{50}$ was 0.03 and $50 \%$ deaths were in between dilution $1 / 5$ to $1 / 25$ (table 3 ). Sodium nitrite significantly lowered both the immune response to RVFV and the antibodies titer. 


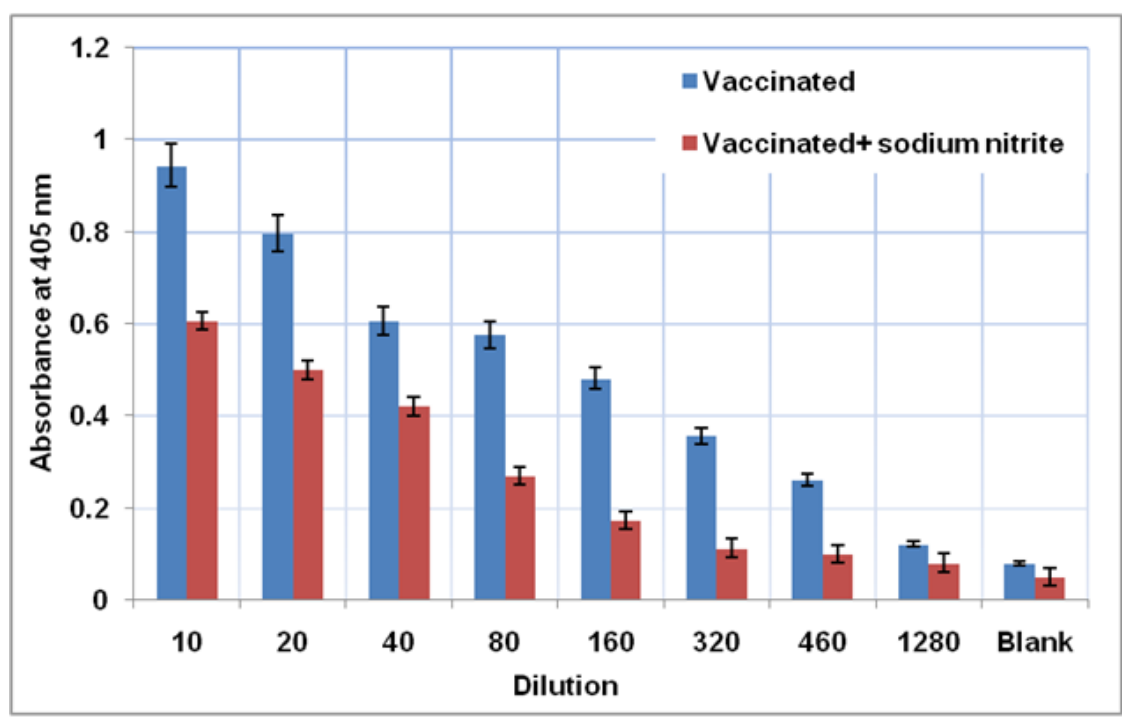

Fig. 1: mean \pm SEM of ELIZA test for detection of IgG antibodies in the sera of vaccinated-mice with or without sodium nitrite. (n=25)

Table 2: Calculation of $\mathrm{ED}_{50} / \mathrm{ml}$ of using Reed and Muench mathematical technique in control vaccinated mice

\begin{tabular}{llllll}
\hline $\begin{array}{l}\text { RVFV } \\
\text { dilution }\end{array}$ & Number & & Cumulative & Mortality ratio \\
\cline { 2 - 5 } & Dead & Alive & Dead & Alive & \\
\hline Undiluted & 0 & 10 & 0 & 27 & $0 / 27$ \\
$1 / 5$ & 0 & 10 & 0 & 21 & $0 / 21$ \\
$1 / 25$ & 0 & 10 & 1 & 16 & $1 / 16$ \\
$1 / 125$ & 4 & 6 & 3 & 7 & $3 / 10$ \\
$1 / 625$ & 10 & 0 & 12 & 0 & $12 / 0$ \\
ED $_{50}$ & 0.01 & & & $30 \%$ & $100 \%$ \\
\hline
\end{tabular}

Table 3: Calculation of $\mathrm{ED}_{50} / \mathrm{ml}$ of using Reed and Muench mathematical technique in vaccinated sodium nitrite-treated mice

\begin{tabular}{llllll}
\hline $\begin{array}{l}\text { RVFV } \\
\text { dilution }\end{array}$ & Number & & Cumulative & Mortality \\
\cline { 2 - 5 } ratio
\end{tabular}

\section{DISCUSSION}

Exposure to sodium nitrite-induced a hepatic injury through several mechanisms including an intensification of oxidative stress and DNA damages and inhibition of mitochondrial function [24]. Moreover, hypoxia on liver, lung, kidney and cardiac tissues was recorded in sodium nitrite-injected male albino rats [25]. The liberations of superoxide, hydroxyl moiety and other free radicals by the extrinsic source of sodium nitrite may be responsible for the autocatalytic stage of the oxidation of hemoglobin to methemoglobin [26]. Nitrite has a strong oxidant effect on RBC membrane and its hemoglobin increases the peroxidation of the phospholipids layers of the plasma membrane and leads to hemolysis [27].

The reduction in TLC after 21-days exposure to sodium nitrite may be due to the failure of the hematopoietic tissues to produce new leucocytes [28] Consequently, the defense mechanism for combating foreign antigens and initiating a primary immune response was reduced.

A dose-dependent manner significant decrease in lymphocyte percentages and an increase in the neutrophil count was obtained after exposure to sodium nitrite in Balb/c mice for $21 \mathrm{~d}$ [29]. The NLR ratio is a rapid immunological assessment for exposure to oxidative stress in rodents after exposure to xenobiotic [20].
Maximum suppression was obtained in natural killer (NK) cell activity (59.2\%), IgM titer (57.5\%) and IgG titer (61.1\%) after treatment with sodium nitrite at $100 \mathrm{mg} / \mathrm{kg}$. It was found that the immunosuppressive effect of sodium nitrite is reversible after cessation of exposure [29].

The exposure to sodium nitrite in Guinea pigs were significantly $(\mathrm{p}<0.05)$ decreased serum total proteins, albumin, and globulin concentrations, and their ratio [30], thus immunodeficiency is expected with the reduced immunoglobulin's levels.

IgG is an essential class of immunoglobulin that is associated with the neutralization of antigen. Re-challenging serum of the same animals with diluted or attenuated viral antigen produce an obvious neutralization reaction [31]. The most important parameters that can be used for monitoring the performance of the potency of a vaccine is the $\mathrm{ED}_{50}$ (dose of vaccine needed to have an effect in $50 \%$ of the animals) and $\mathrm{PD}_{50}$ (dose of the vaccine protecting $50 \%$ of the animals against the effects of a challenge [32]. Results of the potency of the RVFV in mice revealed that the vaccines gave protection in control vaccinated-mice with $\mathrm{ED}_{50} / \mathrm{ml}=0.01$. While RVFV failed to protect deaths in sodium nitrite-treated mice, as the $\mathrm{ED}_{50} / \mathrm{ml}$ was 0.03 as the acceptable ED $50 / \mathrm{ml}$ of RVFV should not be more than 0.02 [33]. 
Environmental pollutants as food additives may act as linking stress that is known to decrease antibody responses to vaccination and impaired immune response following exposure to stress [34].

Sodium nitrite significantly decreased the effectiveness of vaccination through elevating the $\mathrm{ED}_{50}$ value of RVFV vaccine. In this respect, the production of RVFV neutralizing antibodies in challenge mice revealed that the neutralizing humoral response against the RVFV glycoproteins specific CD8+T-cell response and the cellular immunity induced by the nucleoprotein protect against challenge [35]. Oral ingestion of sodium nitrite produces significant inhibition of $\mathrm{T}$ and $\mathrm{B}$ lymphocytes proliferation in mice and this inhibition interferes with both humoral and cellular immunity [29].

\section{CONCLUSION}

Exposure to sodium nitrite is associated with diminishing both cellular and humoral immune responses with an increased risk of infection and failure of routine vaccination in rodents.

\section{ACKNOWLEDGMENT}

This work was financially supported by Cairo University in a project entitled "Assessment of Residual Patterns and Genotoxicity of Some Food Additives Using LMRS (Laser Molecular Raman Spectroscopy)".

\section{AUTHORS CONTRIBUTIONS}

All authors have contributed equally to this manuscript

\section{CONFLICT OF INTERESTS}

\section{Declared none}

\section{REFERENCES}

1. Gerdes GH. Rift valley fever. Vet Clin North Am Food Anim Pract 2002;18:549-55.

2. Ikegami T, Hill TE, Smith JK, Zhang L, Juelich TL, Gong B, et al. Rift valley fever virus MP-12 vaccine is fully attenuated by a combination of partial attenuations in the SM and L Segments. J Virol 2015;89:7262-76.

3. Kortekaas J. One Health approach to rift valley fever vaccine development. Antiviral Res 2014;106:24-32.

4. Kortekaas J. One Health approach to rift valley fever vaccine development. Antivir Res 2014;106:24-32.

5. Scharton D, Van Wettere AJ, Bailey KW, Vest Z, Westover JB, Siddharthan $\mathrm{V}$, et al. Rift valley fever virus infection in golden syrian hamsters. PLoS One 2015;10. Doi:10.1371/ journal.pone.0116722.

6. Al Shammari E, Bano R, Khan S, Shankity I. The effect of preservatives and flavour additive on the production of oxygen-free radicals by isolated human neutrophils. Int J Nutr Food Sci 2014;3:210-5.

7. Elelaimy. Evaluation of sub-chronic chlorpyrifos poisoning on immunological and biochemical changes in rats and protective effect of eugenol. J Appl Pharm Sci 2012;2:51-61.

8. Honikel KO. The use and control of nitrate and nitrite for the processing of meat products. Meat Sci 2008;78:68-76.

9. Sullivan GA, Jackson Davis AL, Schrader KD, Xi Y, Kulchaiyawat C, Sebranek JG, et al. Survey of naturally and conventionally cured commercial frankfurters, ham, and bacon for physiochemical characteristics that affect bacterial growth. Meat Sci 2012;92:808-15.

10. Paulsen P, Smulders FJM. Encyclopedia of meat sciences. 2014. Doi:10.1016/B978-0-12-384731-7.00070-2.

11. Mortensen A, Aguilar F, Crebelli R, Di Domenico A, Dusemund B, Frutos MJ, et al. Re-evaluation of potassium nitrite (E 249) and sodium nitrite (E 250) as food additives. EFSA J 2017;15:4786.

12. Hord NG, Tang Y, Bryan NS. Food sources of nitrates and nitrites: the physiologic contact for potential health benefits. Am J Clin Nutr 2009;90:1-10.

13. Dixon D, Herbert RA, Kissling GE, Brix AE, Miller RA, Maronpot RR. Summary of chemically induced pulmonary lesions in the national toxicology program (NTP) toxicology and carcinogenesis studies. Toxicol Pathol 2008;36:428-39.
14. Lee $\mathrm{CH}$, Cho YH, Park KH. Assessment of estimated daily intake of nitrite by the average consumption of processed foods in Korea. Food Control 2006;17:950-6.

15. Larsson K, Darnerud PO, Ilback NG, Merino L. Estimated dietary intake of nitrite and nitrate in Swedish children. Food Addit Contam-Part A Chem Anal Control Expo Risk Assess 2011;28:659-66.

16. Reddy MV, Aruna G, Parameswari SA, Banu BH, Reddy PJ. Estimated daily intake and exposure of sodium benzoate and potassium sorbate through food products in school children of Tirupati, India. Int J Pharm Pharm Sci 2015;7:129-33.

17. NRC. Guide for the Care and Use of Laboratory Animals: Eighth Edition; 2011. Doi:10.1163/1573-3912_islam_DUM_3825.

18. Ikegami T, Makino S. Rift valley fever vaccines. Vaccine 2009;27 Suppl 4:D69-72.

19. Ziauddin M, Phansalkar N, Patki P, Diwanay S, Patwardhan B. Studies on the immunomodulatory effects of Ashwagandha. J Ethnopharmacol 1996;50:69-76.

20. Swan MP, Hickman DL. Evaluation of the neutrophillymphocyte ratio as a measure of distress in rats. Lab Anim (NY) 2014;43:276-82.

21. Klein Schneegans AS, Gaveriaux C, Fonteneau P, Loor F. Indirect double sandwich ELISA for the specific and quantitative measurement of mouse IgM, IgA and IgG subclasses. J Immunol Methods 1989;119:117-25.

22. Gauger PC, Vincent AL. Serum virus neutralization assay for detection and quantitation of serum-neutralizing antibodies to influenza a virus in swine. Methods Mol Biol 2014;1161: 313-24.

23. Reed LJ, Muench H. A simple method of estimating fifty percent endpoints. Am J Hyg 1938;27:493-7.

24. Salama MF, Abbas A, Darweish MM, El-Hawwary AA, Al-Gayyar MMH. Hepatoprotective effects of cod liver oil against sodium nitrite toxicity in rats. Pharm Biol 2013;51:1435-43.

25. Al Rasheed NM, Fadda LM, Attia HA, Ali HM, Al-Rasheed NM. Quercetin inhibits sodium nitrite-induced inflammation and apoptosis in different rats organs by suppressing Bax, HIF1- $\alpha$, TGF- $\beta$, Smad- 2 , and AKT pathways. J Biochem Mol Toxicol 2017;31. Doi:10.1002/jbt.21883.

26. Kumar MS, Unnikrishnan MK, Patra S, Murthy K, Srinivasan KK. Naringin and naringenin inhibit nitrite-induced methemoglobin formation. Pharmazie 2003;58:564-6.

27. Rodriguez Estival J, Martinez Haro M, Martin Hernando MP, Mateo R. Sub-chronic effects of nitrate in drinking water on red-legged partridge (Alectoris rufa): Oxidative stress and Tcell mediated immune function. Environ Res 2010;110:469-75.

28. Sperandio M, Gleissner CA, Ley K. Glycosylation in immune cell trafficking. Immunol Rev 2009;230:97-113.

29. Abuharfeil N, Sarsour E, Hassuneh M. The effect of sodium nitrite on some parameters of the immune system. Food Chem Toxicol 2001;39:119-24.

30. Hassan HA, El Agmy SM, Gaur RL, Fernando A, Raj MHG, Ouhtit A. In vivo evidence of the hepato-and reno-protective effect of garlic oil against sodium nitrite-induced oxidative stress. Int J Biol Sci 2009;5:249-55. doi:10.7150/ijbs.5.249.

31. Li Y, Yao J, Han C, Yang J, Chaudhry MT, Wang S, et al. Quercetin, inflammation, and immunity. Nutrients 2016;8:167.

32. Kundi M. One-hit models for virus inactivation studies. Antiviral Res 1999;41:145-52.

33. Gamal WM, Mohamed Soliman EM, El-Manzalawy MA. Tracing the antibody-mediated acquired immunity by Foot and Mouth disease and rift valley fever combined vaccine in pregnant ewes and their lambs. Vet World 2014;7:922-8.

34. Keylock KT, Lowder T, Leifheit KA, Cook M, Mariani RA, Ross K, et al. Higher antibody, but not cell-mediated, responses to vaccination in high physically fit elderly. J Appl Physiol 2007;102:1090-8.

35. Lorenzo G, Martin Folgar R, Hevia E, Boshra H, Brun A. Protection against lethal Rift Valley fever virus (RVFV) infection in transgenic IFNAR-/-mice induced by different DNA vaccination regimens. Vaccine 2010;28:2937-44. 